\title{
東日本大震災後の学会連携と 防焱学術連携体の設立
}

依田照彦

\section{1. 東日本大震災後の 防災関連の学会連携}

多様で媣刻な数々の災害を乗り越え、経済発 展を成し遂げてきた我が国であるが、2011年3 月11日に発生した東日本大震災による深刻な 津波災害および原子力事故は、我が国の防災・ 減災・国土政策に大きな課題をつきつけた。防 災・減災・国土政策分野は非常に多くの分野が 相互に関係するものであり、多くの関係省庁、 自治体、研究機関、大学等が密接に連携して、 今後の対策の立案・実施を進めていく必要があ る。日本学術会議土木工学・建築学委員会の 呼びかけで2011年5月に集まった関連24学協 会による「東日本大震災の総合対応に関する学 協会連絡会」（以降、学協会連絡会とよぶ）は、 このような我が国の現状に鑑み、従来の枠組み を超えてより多くの関係者が情報交換・議論す ることにより、東日本大震災および我が国が将 来直面するであろう災害に対して、より適切な 対応・対策を実現することを目的として、連続 シンポジウムを開催してきた。参加学会は、理 学・工学にとどまらず、医学関係、経済学関係 も含む多様な構成となった。設立時の学会数は 24 であり、その後に増えて 30 学会となった。 この学協会連絡会の役割は大きく二つあった。 東北地方太平洋沖地震の被害の全容解明と災害 の総括を分野横断的に行うこと、および将来の 自然災害の軽減に向けて、分野横断で取り組む
べき課題を抽出して、これらに対して連携して 取り組むことであった。自然災害軽減のための 分野横断的取組みが不可欠であることは長い間 指摘されてきたが、分野間や学会間の壁があり、 実現には至らなかった経緯がある。日本学術会 議による学協会連絡会が分野横断による防災に 関する調査研究の核となってその役割を果たす ことが期待された。

\section{2. 連続シンポジウムによる 学会連携の拡大・充実}

2011年 12 月から 2014年11月までに、日本学 術会議の講堂において、日本学術会議と学協会 連絡会は、「巨大災害から生命と国土を護る一 三十学会からの発信」を統一テーマとしてシン ポジウムと学術フォーラムを合わせて 10 回開 催した。そこでは、巨大災害リスクの高まりつ つある日本が直面している契緊の課題を正面か ら取り上げて議論した。このうちの8回、9回、 10 回のシンポジウムでは、30学会の会長が勢 揃いして、活発な議論を展開した。異なる分野 を代表する学識者の討論は話題をよび、日本学 術会議の講堂は毎回満席であった。

一連の学協会連絡会の活動の成果の一つに、 2012 年 5 月 10 日に発表した「三十学会・共同声 明 国土・防災・減災政策の見直しに向けて」が ある。この共同声明は、異なる分野のすべての 学会の理事会で承認された総意の声明文であ 
る。学会の代表が集まり、国土交通大臣、内閣 府防災担当大臣、文部科学副大臣に共同声明を 手交できた。

さらに、2013年には連続シンポジウムの各回 で議論された内容を総括するとともに、今後の 学術の方向性と基本政策について関連する学協 会が整理し、その成果を広く国民に向けて発信 することを意図して、『学術の動向』3月号に特 集「巨大災害から生命と国土を護る一三十学会 からの発信」を掲載した。

2014年11月には、学術フォーラム「東日本 大震災・阪神淡路大震災の経験を国際的にどう 活かすか」を開催した。これは、我が国の防災・ 減災に関連する諸学会、および社会経済や医学 等の幅広い分野の学識者が集まり、東日本大震 災・阪神淡路大震災をはじめとするこれまでの 自然災害から得られた知見を、世界の防災・減 災にどう活かしていくべきかを、分野の壁を越 えて議論するものであった。この成果として、 30 学会の理事会の承認を得て、英文の共同声明 $\lceil$ Global sharing of the findings from the Past Great Earthquake Disasters in Japan」を発出 するとともに、学協会連絡会に所属する各学会 の大震災に関する取組みと国際的な活動を紹介 する冊子を作成した。この共同声明は、2015年 1月の「防災・減災に関する国際研究のための 東京会議」(東京都) をはじめ、2015年3月の 国連防災世界会議（仙台市）、2015年5月のア ジア学術会議（カンボジア）、2015年11月の世

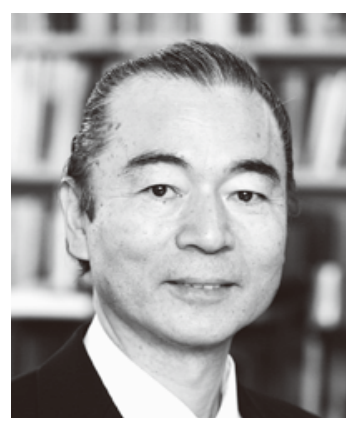

\section{PROFILE}

依田照彦

(よだ てるひこ)

日本学術会議連携会員、防災学術連 携体副代表幹事、早稲田大学理工学 術院社会環境工学科教授 専門 : 構造工学、橋梁工学

界工学会議（京都市）で、発表・配布された。 これまで東日本大震災以降、日本学術会議の 会員・連携会員が主導して、30学会が連携す る東日本大震災の総合対応に関する学協会連絡 会をつくり、10回の連続シンポジウムや共同声 明を発表してきたが、この取組みをさらに発展 させ、地震や津波だけでなく、自然災害全般の 防災減災を対象に、より広い分野の学会の参画 を得て次の災害に備えるべく、「防災学術連携 体」の設立にあわせて、学協会連絡会としての 連続シンポジウムの第11回（最終回）として、 2016年1月9日に日本学術会議主催学術フォー ラム「防災学術連携体の設立と東日本大震災の 総合対応の継承」を開催した。

各回のシンポジゥムで議論した内容につい ては、シンポジウムの参加者やホームページ上 に公開した内容などにより、学協会やその他多 くの機関における活動に反映されている。連続 シンポジウムの過去11回の内容はhttp://www. janet-dr.com/07_event/event00.htmlに詳しい。 


\section{3. 日本学術会議と} 防災学術連携体との学術連携

学協会連絡会の活動は、日本学術会議の会員· 連携会員が主導して、大きなテーマのもとで学 会横断的な取組みを進め、一定の成果を挙げた 一つの例として評価されているものの、日本列 島の地震活動が活発化し、南海トラフ地震や首 都直下地震の発生が危惧されると共に、地球の 気候変動による自然災害の増加が懸念されてい る現在、専門を越えた取組みにより次の大災害 に備えることが求められている。このような現 状に鑑み、2016年1月9日に、自然災害の軽減 のために、日本学術会議と連携して47の学会 （現在は54学会）が結集し、「防災学術連携体」 が設立された。

背景には、2015年7月に日本学術会議の課題

表 防災減災・災害復興に関する学術連携委員会 委員名簿 $(2016$ 年 9 月現在)

\begin{tabular}{|c|c|c|c|}
\hline & 氏名 & 所属·職名(略称) & 備考 \\
\hline \multirow[t]{5}{*}{ 副委員長 } & 小松久男 & 東京外国語大学特任教授 & 第一部会員 \\
\hline & 石川冬木 & 京都大学教授 & 第二部会員 \\
\hline & 向井千秋 & 東京理科大学特任副学長 & 第二部会員 \\
\hline & 大西 隆 & 豊橋技術科学大学学長 & 第三部会員 \\
\hline & 大野英男 & 東北大学教授 & 第三部会員 \\
\hline & 米田雅子 & 慶應義塾大学特任教授 & 第三部会員 \\
\hline & 小池俊雄 & 東京大学教授 & 連携会員 \\
\hline & 中島映至 & 宇宙航空研究開発機構セン夕一長 & 連携会員 \\
\hline & 林 春男 & 防災科学技術研究所理事長 & 連携会員 \\
\hline & 藤井克己 & 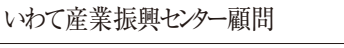 & 連携会員 \\
\hline & 依田照彦 & 早稲田大学教授 & 連携会員 \\
\hline 委員長 & 和田 章 & 東京工業大学名誉教授 & 連携会員 \\
\hline 事 & 熊谷 博 & 情報通信研究機構研究セン夕一長 & 特任連携会員 \\
\hline
\end{tabular}

別委員会として「防災減災・災害復興に関する 学術連携委員会」(以降、学術連携委員会とよぶ) が設置されたことがある。日本学術会議は、東 日本大震災の経験を踏まえて、大規模自然災害 の発生時などの緊急事態時において、学術の知 見を的確に活用することが必要との観点から、 「緊急事態における日本学術会議の活動に関す る指針」（2014年2月28日）を作成した。その 中で、緊急事態時には、幹事会を中心とした緊 急事態対策委員会を設置して、声明・提言等の 表出、政府への協力や連携、社会との連携、さ らに関連分野の研究者との幅広い連携を行うこ とを決めた。こうした観点から、自然環境・八 ザード観測、防災・減災、救急・救助・救援、 復旧・復興の研究に関わる日本学術会議協力学 術研究団体を含めた国内外の学術団体や研究グ ループとの平常時、緊急事態時における連携の 在り方について検討することを目的に先述の学 術連携委員会が設置された。表に示すように、 第三部だけでなく第一部、第二部からの委員参 加を得て活動を開始することとなった。さらに、 和田章委員長が防災学術連携体の代表幹事に選 出され、多くの委員が防災学術連携体の活動に も参画したことにより、現在、両組織間には緊 密な連携が図られている。

\section{4. 熊本地震で始動した 防災学術連携体}

大災害等の緊急事態にも対応できる継続性 
のある学会ネットワークを構築することを念頭 に、ウェブサイトや連絡網の充実を図っている 矢先、熊本地震が発生した。2016年 4 月 14 日の 前震と 16 日未明の本震である。この緊急事態 に対応するために、防災学術連携体に所属する 学会から、異なる分野の専門家有志が集まり、 この地震に関する最新の情報を報道関係者に提 供する機会を作るために「緊急共同記者会見」 を4月18日に土木学会において開催した。この 時点で、日本学術会議は、熊本地震災害を 2014 年 2 月に制定した「緊急事態における日本学術 会議の活動に関する指針」の「緊急事態に準じ るもの」と判断した。これを受けて、日本学 術会議の学術連携委員会は、防災学術連携体と 連携して、5月 2 日に「熊本地震・緊急報告会」 を開催し、17学会が調查速報の発表を行い、社 会への情報発信・学会間の情報共有を進めた。 このように、学術連携委員会と連携して活動し 始めていた防災学術連携体は、熊本地震発生後、 緊密に連携を取り合い、4月18日の「緊急共同
記者会見」 5 月 2 日の「熊本地震·緊急報告会」、 7月 16 日の「熊本地震・ 三ヶ月報告会」を開催 することができた。

罒に示すように、日本学術会議と連携した防 災学術連携体は防災推進国民会議の一員として 活動しており、2016年8月27日、28日に開催 された第 1 回防災推進国民大会においては、8 月 28 日午前に「第 1 回防桨学術連携シンポジウ ム 52 学会結集による防災への挑戦一熊本地震 における取組み一」28日の午後には二つのワー クショップ「火山災害にどう備えるか」と「東 京圈の大地震にどう備えるか」を開催した。熊 本地震に関する防災学術連携体の取組みの詳細 については、本特集における塚田幸広氏の報告 を参照されたい。

\section{5. おわりに}

防災学術連携体には、日本学術会議と連携し て平常時から学会間の連携を深め、大災害等の 緊急事態時には、日本学術会議 とともに、学会間の緊急の連絡 網として機能することが期待さ れている。大災害への備えと対 応は長期にわたるため、平常時 から政府・自治体・関係機関と の連携を図るとともに、緊急事 態時に円滑な協力関係が結べる ように、ネットワークの継続性 に配慮したい。

図 防災学術連携体のネットワーク（米田雅子防災学術連携体事務局長作成） 